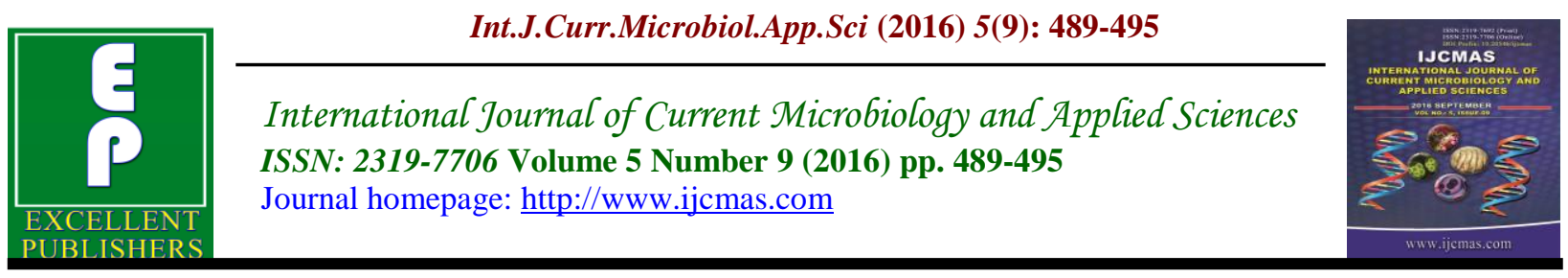

Original Research Article

http://dx.doi.org/10.20546/ijcmas.2016.509.054

\title{
Molecular Distinction of Algae using Molecular Marker
}

\author{
B.K. Chikkaswamy and Rabin Chandra Paramanik*
}

Om Bio Science Research Centre, Indiranagar, Bangalore, India

*Corresponding author

Keywords

Genetic diversity, chlorococcales, RAPD, strains, geographical region.

\section{Article Info}

Accepted:

20 August 2016

Available Online:

10 September 2016

\section{A B S T R A C T}

RAPD molecular method is the Expressed Sequence database was used as the original genomic information for identification of polymorphic sites. Primers OPW-04, 05 and 06 RAPD is designed and the amplified PCR products are then directly sequenced. All sequences obtained are aligned to search possible RAPD altering the restriction enzymes recognition sites. At last, the method is used to genotype of these RAPD markers in large population samples of the of chlorococcales species complex. The physico-chemical parameters like phosphate and nitrate exhibit a positive correlation with the dynamics of chlorococcales. The results showed that 70,69 and 75 RAPD bands with Primer OPW-0showed geographical discrimination. Molecular markers in algae and can be more relevant than other neutral markers mentioned above due to the high occurrence of RAPD in their functional genomic regions. Because of the potential for higher genotyping efficiency, data quality, genome-wide coverage, and analytical simplicity, RAPD have been used as molecular markers in evolutionary and ecological studies of a wide range of organisms in the current study, we report the characterization of 19 species of ofchlorococcales4, OPW-05 and OPW- 06are useful for genetic diversity studies of chlorococcales as they.

\section{Introduction}

Algae are one of the most useful natural resources that can be used to produce different bioactive compounds such as vitamins, proteins, unsaturated fatty acids, antioxidants and carotenoids, including astaxanthin. During the past two decades, scientists have discovered that Haematococcus, a unicellular green alga, is the best source of organisms that produce astaxanthin, the most powerful naturally occurring antioxidant. Astaxanthin can be used as a preventive medicine, by being able to slow down degenerative diseases and cardiovascular problems, having anti-cancer and anti-immunological disease properties and finally, its ability to stimulate the proliferation of neural progenitor cells to recover stem cell function. Morphological traits observed through the light microscope have been traditionally used to determine the species and the diversity of Algae, which has a complex life cycle with different morphological stages affected by environmental conditions. The morphology alone is not able to recognize strains which have various shapes in diverse 
environmental conditions and the cryptic species (due to recent speciation) with similar morphological traits however they are different genetically. Molecular and genetic characters are affected less than the morphological characters by environmental conditions, hence they are more stable. In addition to the necessity of the morphological study, there is a need to the molecular study of organisms in order to differentiate them geographically. The combination of molecular and morphology provide a robust way to determine organisms with lower mistakes. Biotechnological methods and molecular markers are great promising tools for improvement and enhancement of biomass production, astaxanthin production and tolerance to stresses in Algae. Most of the molecular marker tools are valuable methods to investigate population genetic and diversity which were developed quickly over the three past decades. There have been some studies on algae using Inter Simple Sequence Repeat (ISSR) and Random Amplified Polymorphic DNA (RAPD) molecular markers; however, there have been none thus far on $H$. pluvialis. Therefore, this study was conducted for the first time with the aim of remedying this situation. ISSR markers are reliable, highly polymorphic, low cost and less laborious, need only a small amount of DNA and are very fast when compared to most other molecular markers .

Sequence data and in terms of reproducibility, ISSR is comparable to SSR. The RAPD technique has wide applications in breeding, genetic evolution, gene mapping and population genetics and is able to produce many markers with low cost and high speed. Although the reproducibility of RAPD technique is low and is dominant, it is one of the important molecular markers. The SNP technique is a dominant marker too but its reproducibility is higher than RAPD. Molecular and genetic study of any organism needs pure and axenic cultures whereas the growth of Algaeis very difficult due to their sensitivity to contamination. The $\mathrm{pH}$ of medium is neutral and other algal species, bacteria or fungi easily can dominate and make a culture fail. The molecular markers are able to distinguish other strains of Algae with desirable properties from various parts of the world.

The advent of recombinant DNA technology heralded a morphologically completely approach to define potentially polymorphic DNA sequences. This new technology promises to revolutionize some areas of plant genetics and plant breeding. The markers based on DNA sequences have introduced a new dimension to the development of genetic maps and mapping of and physiologically important characters.

The objective of this study was to find out the genetic diversity and relationships of the different green unicellular algae, by using SNP and RAPD markers and nif gene sequencing. There is a tendency to depend on the culture collection institutes that represents a limitation for scientists. This dependency on culture collections can deprive researchers from access to new species and strains with diverse characteristics and various bioactive compounds which can be found in other habitats.

Four new strains were isolated from different cities of Tumkur in order to examine their diversity and to uncover their differences with CCAP (Culture Collection of Algae) strains, using molecular markers. If useful the new strains isolated from Tumkur water bodies could be deposited in culture collections in order to enrich the gene reserves. 
In India there are thousands of collections of Algae whose genotypic status is not known. Besides an in-depth molecular marker genetic analysis of Algae has not been carried out so far. By making use of the molecular marker technology based on PCR approach, the diverse Algal species will be analyzed. The present investigation was carried out with the following objective isolation of genomic DNA from collecting samples of different phytoplankton.

\section{Methodology}

Collection and conservation of Ankistrodesmus falcatus (Corda) Ralfs, Ankistrodesmus Spiralis (Turner) Lemm. V fasciculatus, Closteriopsis longissima Lemm, Coelastrum microsporum, Crucigenia crucifera, Gonatozygon kinahanii, Micractinium pussillum, Pediastrum duplex var. coronatum, $P$. duplex var.clathratum, $P$. duplex var. reticulatum, $P$. simplex, $P$. teras var. tetraedon, Scenedesumus accuminatus, $S$. arcuatus, S. bijiugatus var. bicellularis, $S$. dimorphous, S. platidiscus, S. protuberans, S. quadricauda var. maxima.

\section{Genomic DNA isolation: For RAPD and SNP}

The 19 Algal samples were collected from different regions of Tumkur dist is subjected to DNA Extraction. Total DNA was extracted using Cetyltrimethly ammonium bromide (CTAB) method described by Doyle and Doyle (1990) with minor modification. Quality and quantity of DNA will be analyzed by both gel electrophoresis and spectrometric assays using UV-visible double beam pc scanning spectrophotometer

DNA Amplification: Polymerase Chain reaction (PCR) amplification will be performed in a volume of $20 \mathrm{ul}$ comprising 1.5 units of taq DNA polymerase. $1 \mathrm{x}$ taq assay buffer (10 mMTris-Hcl, $1.5 \mathrm{Mm}$ mgcl2, $50 \mathrm{Mm} \mathrm{kcl}$ add 2.01 gel stained ph 9.0) 200 um of primer, $200 \mathrm{um}$ of dNTPs and $50 \mathrm{mM} 50$ DNA template. Amplification will be performed in thermo cycler. The optimized PCR Condition for both RAPD and AFLP will be determined. The amplified products will be separated by electrophoresis on $1.25-1,5 \%(\mathrm{w} / \mathrm{v})$ agarose gels for 75-100 volts in 1x TBE buffer (TrisBorate-EDTA buffer). After completion of electrophoresis, gels will be stained with ethidium bromide solution. The amplified products in gels will be visualized and photographed using gel documentation bioprofile image analysis system. The size of the amplification products will be determined by comparisons to lambda DNA/EcoR-Hind 111 double digest DNA ladder. PCR reaction was repeated at least twice to check the reproducibility of the banding.

\section{Results and Discussion}

The genomic of were subjected to RAPD analysis using Primer OPW- 01 The genomic DNA of 19 Ankistrodesmus falcatus (Corda) Ralfs, Ankistrodesmus Spiralis (Turner) Lemm. V fasciculatus, Closteriopsis longissima Lemm, Coelastrum microsporum, Crucigenia crucifera, Gonatozygon kinahanii, Micractinium pussillum, Pediastrum duplex var. coronatum, $P$. duplex var.clathratum, $P$. duplex var. reticulatum, $P$. simplex, $P$. teras var. tetraedon, Scenedesumus accuminatus, S. arcuatus, $S$. bijiugatus var. bicellularis, $S$. dimorphous, S. platidiscus, S. protuberans, S. quadricauda var. maxima. rapd analysis of 19 species of chlorococcales algae amplified with primer, opw - 04The genomic DNA of 19 species of chlorococcales algae was amplified with the oligonucletide primer OPW-04 are shown in the figure 4. The distant and abundant RAPD fragments were recorded. The total 
number of bands are generated were found to be 70.the size of the RAPD band were placed in between 300 to 5000 bp length the primer produced distinct banding patterns . The number of bands per primer is 3.6 as expected in sexually reproducing plants .The RAPD bands distributed in 19 species of chlorococcales algae is known to important. The number of RAPD bands produced to reveal Mendelein inherited character and number scoring revealed divers properties. The banding patterns are important and distinct in algae species. The RAPD banding patterns showed high polymorphism, were useful in distinguishing algal species. 1, 2, 3, 4 revealed 3-4 bands each where as other varieties showed more than 3-5 bands where 18 mulberry species of algae revealed only 2 bands as shown in figure 4.rapd analysis of 19 species of chlorococcales algae amplified with primer, opw - 05, The genomic DNA of 19 species ofchlorococcales algae was amplified with the oligonucletide primer OPW-05 is shown in the figure 5. The distant and abundant RAPD fragments were recorded. The total number of bands are generated were found to be 69.the size of the RAPD band were placed in between 300 to 5000 bp length .the primer produced distinct banding patterns . The number of bands per primer is 3.6 as expected in algae. The RAPD bands distributed in 19 species ofchlorococcales algae known to important. The number of RAPD bands produced to reveal Mendelein inherited character and number scoring revealed divers properties. The banding patterns are important and distinct in algal species. The RAPD banding patterns showed high polymorphism, were useful in distinguishing .Although diverse elements and other characters revealed as many as RAPD bands. The identification of RAPD bands in 19 species of chlorococcales algae is important because of differentially distributed derivatives proteins.

Table.1 Details of the optimal concentrations of the PCR mix

\begin{tabular}{|l|l|l|}
\hline COMPONENTS & RANGE USED & OPTIMAL CONCENTRATION \\
\hline $\mathrm{MgCl}_{2}$ & $1.5 \mathrm{mM}, 2.5 \mathrm{mM}, 3.5 \mathrm{mM}$ & $1.5 \mathrm{mM}$ \\
\hline Template DNA & $10 \mathrm{ng}, 15 \mathrm{ng}, 20 \mathrm{ng}, 25 \mathrm{ng}, 30 \mathrm{ng}$ & $25 \mathrm{ng}$ \\
\hline $\mathrm{dNTPs}$ & $100 \mu \mathrm{M}, 200 \mu \mathrm{M}, 300 \mu \mathrm{M}$ & $200 \mu \mathrm{M}$ \\
\hline
\end{tabular}

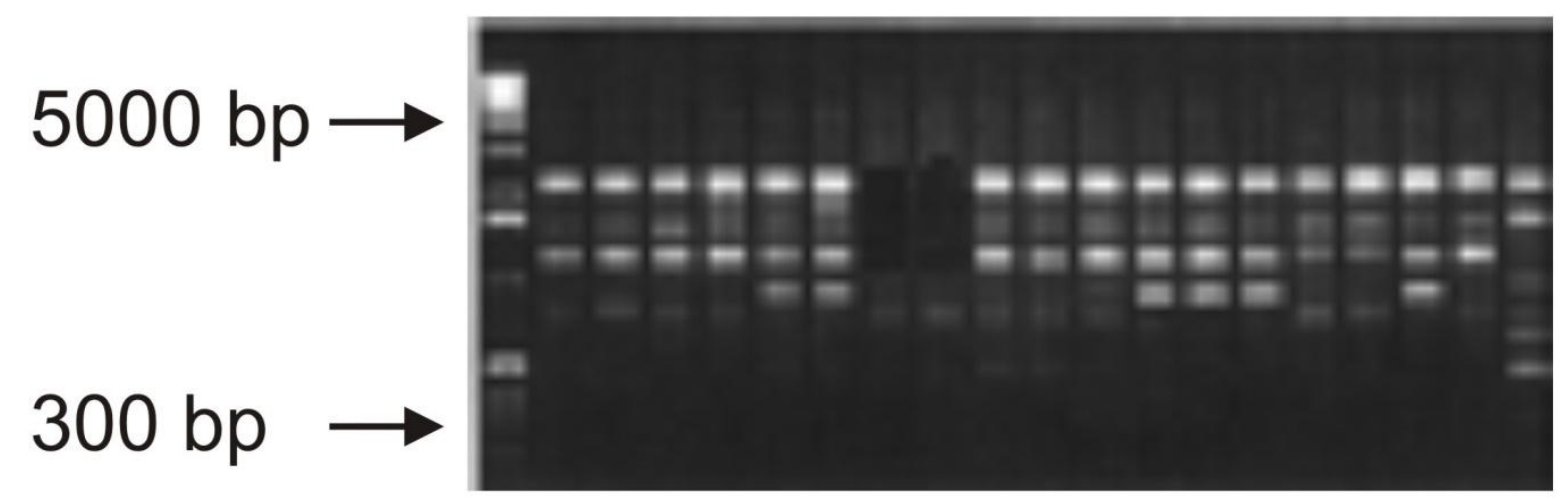

GEL PROFILE OF ALGAE SPECIES AMPLIFIED WITH OPW PRIMER-5 
The marker distribution revealed both polymorphic and mono morphic character. Varieties1, 2, 3, 4 revealed 3 bands each where as other species showed more than 35 bands as shown in figure 5.However, the species 7 and 8 revealed only 1 band each RAPD analysis of 19 species of chlorococcales algae amplified with primer, opw - 06, The genomic DNA of 19 species of chlorococcales was amplified with the oligonucleotide primer OPW-06 is shown in the figure 6 . The distant and abundant RAPD fragments were recorded. The total number of bands are generated were found to be 75 , the size of the RAPD band were placed in between 300 to 5000 bp length .the primer produced distinct banding patterns . The number of bands per primer is 3.9 as expected in algae. The RAPD bands distributed in 19 chlorococcales are known to important. The number of RAPD bands produced to reveal Mendelein inherited character and number scoring revealed divers properties. The banding patterns are important and distinct in algal species. The RAPD banding patterns showed high polymorphism, were useful in distinguishing mulberry varieties. Although diverse elements such as diploid and other characters revealed as many as RAPD bands. The identification of RAPD bands in 19 chlorococcales is important because of differentially distributed derivatives proteins. The marker distribution revealed both polymorphic and mono morphic character. Species 1, 2, 3, 4 revealed 3 bands each where as other species showed more than 3-5 bands the species 13 as not shown any bands as shown in figure 6 .

\section{References}

Arif, I., Bakir, M., Khan, H., Al Farhan, A., Al Homaidan, A., Bahkali, A., Al Sadoon, M.,Shobrak, M. 2010. A Brief Review of Molecular Techniques to
Assess Plant Diversity.Int. J. Mol. Sci., 11: 2079-2096.

Bardakci, F. 2001. Random Amplified Polymorphic DNA (RAPD) Markers. Turk. J. Biol., 25: 185-196.

Bhau, B.S., Medhi, K., Sarkar, T., Saikia, S.P. 2009. PCR based molecular characterization of Nepentheskhasiana Hook Pitcher. Plant Genet. Resour. Crop. Evol., 56: 1183-1193.

Bittencourt-Oliveira, M.C., Massola, J.N.S., Hernandez-Marine, M., Romo, S., Moura, A.N. Taxonomic investigation using DNA fingerprinting in Geitlerinema species (Oscillatoriales, Cyanobacteria). Phycol. Res., 55: 214 221.

Bornet, B., Antoine, E., Bardouil, M., Marcaillou-Le, Baut, C. 2004. ISSR as new markers for genetic characterization and evaluation of relationships among phytoplankton. $J$. Appl. Phycol., 16: 285-290.

Bornet, B., Antoine, E., Francoise, S., Marcaillou, Le., Baut, C. 2005. Development of sequence, characterized amplified region markers from inter simple sequence repeat fingerprints for the molecular detection of toxic phytoplankton Alexanndrium catenella (Dinophyceae) and pseudo Nitzschia Pseudodelicatissiam (Bacillario-phyceae) from French coastline waters. J. Phycol., 41: 704711.

Bornet, B., Branchard, M. 2001. Nonanchored Inter Simple Sequence Repeat (ISSR) Markers: Reproducible and Specific Tools for Genome Fingerprinting. Plant Mol. Biol. Rep., 19: 209-215.

Cianciola, E., Popolizio, T., Schneider, C., Lane, C. 2010. Using MolecularAssisted Alpha Taxonomy to Better Understand Red Algal Biodiversity in Bermuda. Diversity, 2: 946-958. 
Dayananda, C., Sarada, R., Kumar, V., Aswathanarayana, R.G. 2007. Isolation and characterization of hydrocarbon producing green alga Botryococcus braunii from Indian freshwater bodies. Electron. J. Biotechnol., 10: 78-91.

Dellaporta, S.L., Wood, J., Hicks, J.B. 1983. A plant DNA mini-preparation Version II. Plant Mol. Biol. Reptr., 1: 19-21.

Ferna'ndez, M., Figueiras, A., Benito, C. 2002. The use of ISSR and RAPD markers for detecting DNA polymorphism, genotype identification and genetic diversity among barley cultivars with known origin. Theor. Appl. Genet., 104: 845-851.

Grossa, G.J., Lockwood, S.F. 2004. Cardio protection and myocardial salvage by a disodium disuccinateas taxanthin derivative (CardaxTM). Life Sci., 75: 215-224; Mol., 16.

Hall, M.M., Vis, M.L. 2002. Genetic variation in Batrachospermum helminthosum Batrachospermales, Rhodophyta) among and within stream reaches using inter simple sequence repeat molecular markers. Phycol. Res., 50: $155-162$.

House D.L., Sherwood, R.A., Vis, L.M. 2008. Comparison of three organelle markers for phylogeographic inference in Batrachospermum helminthosum (Batrachospermales, Rhodophyta) from North America. Phycol. Res., 56: 6975.

Huangfu, C., Song, X., Qiang, S. 2009. ISSR variation within and among wild Brassica juncea populations: implication for herbicide resistance evolution. Genet. Resour. Crop. Evol., 56: 913-924.

Hughes, D.A. 1999. Effects of dietary antioxidants on the immune function of middle-aged adults. Proc. Nutr. Soc., 58: 79-84.

Kim, J., Nam, S., Kim, B., Choi, W., Lee, J.,
Kim, W., Choi, Y. 2010. Astaxanthin Improves Stem Cell Potency via an Increase in the Proliferation of Neural Progenitor Cells. Int. J. Mol. Sci., 11: 5109-5119.

Martı'nez, R., Añ̃'barro, C., Ferna'ndez, S. 2006. Genetic variability among Alexandrium tamarense and Alexandrium minutum strains studied by RAPD banding pattern analysis. Harmful Algae, 5: 599-607.

Park, Y., Lee, J.K., Kim, N. 2009. Simple Sequence Repeat Polymorphisms (SSRPs) for Evaluation of Molecular Diversity and Germplasm Classification of Minor Crops. Mol., 14: 4546-4569.

Prevost, A., Wilkinson, M.J. 1999. A new system of comparing PCR primers applied to ISSR fingerprinting of potato cultivars. Theor. Appl. Genet. 98: 107-112.

Rahimmalek, M., Bahreininejad, B., Khorrami, M., Tabatabaei, B.E.S. 2009. Genetic Variability and Geographic Differentiation in Thymus daenensis subsp. daenensis, an Endangered Medicinal Plant, as Revealed by Inter Simple Sequence Repeat (ISSR) Markers. Biochem. Genet., 47: 831-842.

Rohlf, F. 2001. NTSYS-pc Numerical Taxonomy and Multivariate Analysis System; Exeter Software: New York, NY, USA.

Samuel, F.L., Marc, S.P., Stanley, L., Hazen, Z.B., Ferenc, Z. 2006. The effects of oral Cardax $^{\mathrm{TM}}$ (disodium disuccinateas taxanthin) on multiple independent oxidative stress markers in a mouseperitoneal inflammation model: influence on 5-lipoxygenase in vitro and in vivo. Life Sci., 79: 162-174.

Singh, R., Zaki, N.M., Ting, N., Rosli, R., Soon-Guan, T., Leslie, L.E., Ithnin, M., Cheah, S. 2008. Exploiting an oil palm 
EST database for the development of gene-derived SSR markers and their exploitation for assessment of genetic diversity. Biologia, 63: 227-235.

Sokal, R.R., Sneath, P.H.A. 1963. Principles of Numerical Taxonomy; W. H. Freeman: San Francisco, CA, USA. Sample Availability: Samples of the ten of $H$. pluvialis strains are available from the authors.
Zhao, K.G., Zhou, M.Q., Chen, L.Q. 2007. Genetic diversity and discrimination of Chimonanthus praecox (L.) Link germplasm using ISSR and RAPD markers. HortSci., 42: 1144-1148.

Zietkiewicz, E., Rafalski, A., Labuda, D. 1994. Genome fingerprinting by simple sequence repeat (SSR) anchored polymerase chain reaction amplification. Genetics, 20: 176-183.

\section{How to cite this article:}

Chikkaswamy, B.K., and Rabin Chandra Paramanik. 2016. Molecular Distinction of Algae using Molecular Marker. Int.J.Curr.Microbiol.App.Sci. 5(9): 489-495.

doi: http://dx.doi.org/10.20546/ijcmas.2016.509.054 